\title{
Deteksi Parasit Plasmodium pada Citra Mikroskopis Hapusan Darah dengan Metode Deep Learning
}

\section{NOR KUMALASARI CAECAR PRATIWI, NUR IBRAHIM, YUNENDAH NUR FU'ADAH, SYAMSUL RIZAL}

Teknik Telekomunikasi, Fakultas Teknik Elektro, Universitas Telkom, Indonesia

Email: caecarnkcp@telkomuniversity.ac.id

Received 26 September 2020 | Revised 17 Oktober 2020 | Accepted 27 Oktober 2020

\begin{abstract}
ABSTRAK
Parasit plasmodium merupakan makhluk protozoa bersel satu yang menjadi penyebab penyakit malaria. Plasmodium ini dibawa melalui gigitan nyamuk anopheles betina. Dalam World Malaria Report 2015 menyatakan bahwa malaria telah menyerang sedikit 106 negara di dunia. Di Indonesia sendiri, Papua, NTT dan Maluku merupakan wilayah dengan kasus positif malaria tertinggi. Malaria telah menjadi masalah yang serius, sehingga keberadaan sistem diagnosa otomatis yang cepat dan handal sangat diperlukan untuk proses perlambatan penyeberan dan pembasmian epidemi. Dalam penelitian ini akan dirancang sistem yang mampu mendeteksi parasit malaria pada citra mikroskopis darah menggunakan arsitekur Convolutional Neural Network (CNN) sederhana. Hasil pengujian menunjukkan bahwa metode yang diusulkan memberikan presisi dan recall sebesar 0,98 dan f1-score sebesar 0,96 serta akurasi 95,83\%.
\end{abstract}

Kata kunci: parasit, malaria, convolutional neural network, citra mikroskopis

\begin{abstract}
Plasmodium parasites are single-celled protozoan creatures that cause malaria. Plasmodium is carried through the bite of a female Anopheles mosquito. The World Malaria Report 2015 states that malaria has attacked at least 106 countries in the world. In Indonesia itself, Papua, NTT and Maluku are the regions with the highest positive cases of malaria. Malaria has become a serious problem, so the existence of a fast and reliable automatic diagnosis system is indispensable for the process of slowing down the spread and eliminating the epidemic. In this study, a system capable of detecting malaria parasites in microscopic images of blood will be designed using a simple Convolutional Neural Network (CNN) architecture. The test results show that the proposed method provides precision and recall of 0,98, f1-values of 0.96 and accuracy of $95,83 \%$.
\end{abstract}

Keywords: parasites, malaria, convolutional neural network, microscopic image 
Deteksi Parasit Plasmodium pada Citra Mikroskopis Hapusan Darah dengan Metode Deep Learning

\section{PENDAHULUAN}

Malaria menjadi penyakit serius yang disebabkan oleh parasit dari genus plasmodium, ditularkan ke manusia melalui gigitan nyamuk betina dari spesies anopheles yang sebelumnya telah terinfeksi (Talapko, 2019). Penyakit malaria paling umum ditemukan di Sub-Saharan Afrika (SSA), pada tahun 2018 menyumbang sekitar 94\% kematian akibat malaria di seluruh dunia, dimana 64\% adalah anak di bawah usia lima tahun (WHO, 2019), (Ouedraogo, 2020). Sedangkan di Indonesia, data tahun 2015 menyebutkan bahwa Papua, Papua Barat, NTT, Maluku dan Maluku Utara adalah lima provinsi dengan angka Annual Parasite Incidence (API) malaria tertinggi (Kemenkes, 2016). API sendiri adalah angka kasus positif malaria per 1000 penduduk dalam rentang waktu satu tahun. Malaria memiliki beberapa gejala yang sangat mudah dikenali seperti; demam, kesulitan bernapas, kelelahan, dan sakit kepala akut. Gejala malaria muncul dalam 10 sampai 15 hari setelah gigitan infektif (Chanda, 2020). Terdapat beberapa metode yang digunakan dalam diagnosa malaria, yang paling sederhana yaitu mikroskopis, Rapid Diagnostic Tests (RDT), sampai dengan metode Polymerase Chain Reaction (PCR) (Mbanefo \& Kumar, 2020).

Selain metode diagnosa medis di atas, banyak juga peneliti yang melakukan studi terkait diagnosa malaria berbasis citra medis, termasuk menggunakan machine learning. Kehadiran sistem diagnosis berbasis pengolahan citra ini diharapkan mampu mempercepat proses screening awal apakah seseorang sudah terinfeksi parasit plasmodium. Penelitian yang dilakukan oleh Tasdemir Qanbar dan melakukan pendekatan deep learning dengan menggunakan lima arsitektur berbeda, yaitu; Alexnet, VGG16, MobileNetV2, ResNet50 dan RAN (Qanbar, 2019). Hasil pengujian diperoleh bahwa RAN menghasilkan akurasi terbaik sebesar 95,51\% dan MobileNetV2 memberikan performansi terburuk dengan akurasi sebesar $50 \%$. Masud dkk melakukan penelitian terkait deteksi parasit malaria menggunakan model CNN yang terdiri dari empat blok konvolusi dan dua lapis fully connected (Masud, 2020). Setiap blok konvolusi terdiri dari lapis konvolusi, max pooling, batch normalization dan dropout. Pengujian dilakukan untuk epoch 50, batch size 32, SGD optimizer serta skenario perubahan nilai learning rate pada rentang $1 \times 10^{-5}$ sampai $1 \times 10^{-1}$. Performansi sistem ditinjau dari parameter akurasi, AUC, presisi, recall, sensitivitas, f1-score dan MCC. Hasil penelitian memberikan nilai akurasi sebesar 97,3\%, AUC, presisi, recall, sensitivitas dan f1-score sebesar 0,97, serta MCC sebesar 0,9417. Penelitian yang dilakukan Qanbar dan Masud ini menggunakan dataset yang sama, terdiri dari 27.558 citra yang dibagi ke dalam dua kelas, yaitu terinfeksi parasit dan tidak terinfeksi. Penelitian selanjutnya dilakukan oleh Shah dkk, melakukan deteksi parasit malaria menggunakan CNN sederhana yang terdiri dari tiga convolutional layer, dimana setiap layer menggunakan filter sebanyak 32, 64 dan 128 (Shah, 2020). Model didesain dengan menggunakan aktivasi RelU, algoritma pengoptimalan Adam, dan dropout sebesar 50\%. Jumlah data yang digunakan adalah 17.460 citra, dibagi menjadi 8.760 citra terinfeksi parasit dan sisanya sebagai citra tidak terinfeksi. Hasil pengujian untuk deteksi citra terinfeksi adalah nilai akurasi sebesar 95,26\% dan error rate sebesar $4.74 \%$. Sedangkan pada saat melakukan deteksi terhadap citra tidak terinfeksi, performansi sistem terukur dengan nilai akurasi sebesar 94,28\% dan error rate 5,72\%. Pada tahun 2017 Kristofer, Pilarita dan Prospero melaporkan hasil penelitain terkait deteksi parasit malaria menggunakan arsitektur Inception v3 CNN, dengan total dataset terdiri dari 363 citra berukuran $2592 \times 1944$ piksel (Penas, 2017). Hasil pengujian diperoleh akurasi dan sensitivitas masing-masing sebesar 92,4\% dan 95,2\%. Zein melakukan penelitian terkait deteksi penyakit malaria menggunakan citra medis dengan arsitektur CNN ResNet, diperoleh akurasi pengujian sebesar 97\% (Zein, 2019). Dalam laporan penelitiannya, tidak ditemukan informasi terkait kedalam hidden layer Resnet dan jumlah data latih/uji yang digunakan. 
Pada penelitian-penelitian terdahulu yang telah disebutkan di atas, umumnya telah menghasilkan kinerja sistem yang baik (akurasi diatas 90\%), tetapi harus dibayar dengan tingkat komplesitas sistem yang tinggi. Adapun sistem yang dibangun dengan model sederhana (tiga lapis konvulusi saja) tetapi memiliki kelemahan pada terbatasnya jumlah data yang digunakan. Menjawab kelemahan tersebut, dalam penelitian ini akan dibangun sebuah sistem deteksi parasit malaria pada citra mikroskopis hapusan darah menggunakan model CNN sederhana. Total citra dalam dataset berjumlah 27.560 citra, terbagi menjadi citra terinfeksi parasit dan tidak terinfeksi parasit.

Rumusan masalah yang akan diangkat dalam penelitian diantaranya adalah merancang sistem deteksi keberadaan parasit plasmodium pada citra mikroskopis darah menggunakan arsitektur CNN sederhana, menganalisa performansi sistem ditinjau dari nilai presisi, recall, f1-score dan akurasi. Analisa performansi dilakukan terhadap skenario penggunaan algoritma optimasi yang berbeda-beda. Adapun yang menjadi tujuan dari penelitian ini bukan memberikan kebaruan metode untuk deteksi parasit plasmodium, tetapi dapat dijadikan sebagai overview dalam penelitian yang terkait deteksi berbasis citra. Tulisan ini diharapkan mampu memberikan gambaran menyeluruh tentang keberadaan sistem deteksi parasit plasmodium sebagai upaya untuk membantu tenaga medis dalam percepatan proses diagnosa klinis.

\section{METODOLOGI PENELITIAN}

\subsection{CNN}

Convolutional Neural Networks (CNN), merupakan jenis neural network yang kerjanya menyerupai proses kerja otak manusia (Kim, 2017). Beberapa tahun terakhir, CNN telah banyak digunakan dalam deteksi citra medis seperti retina, fundus, rontgen dada, CT X-ray, kanker payudara, analisis citra jantung, perut dan muskuloskeletal. CNN yang dalam beberapa sumber juga menuliskan sebagai ConvNets, dibangun oleh setidaknya 4 komponen, yaitu convolutional layer, pooling layer, fungsi aktivasi dan fully connected layer (Indolia, 2018). Seperti yang telihat pada Gambar 1 dibawah, CNN akan mengatur neuron-neuromya dan membentuknya menjadi tiga dimensi (lebar, tinggi dan kedalaman), di akhir neuron akan didefinisikan sebagai satu layer (Hariyani, 2020).

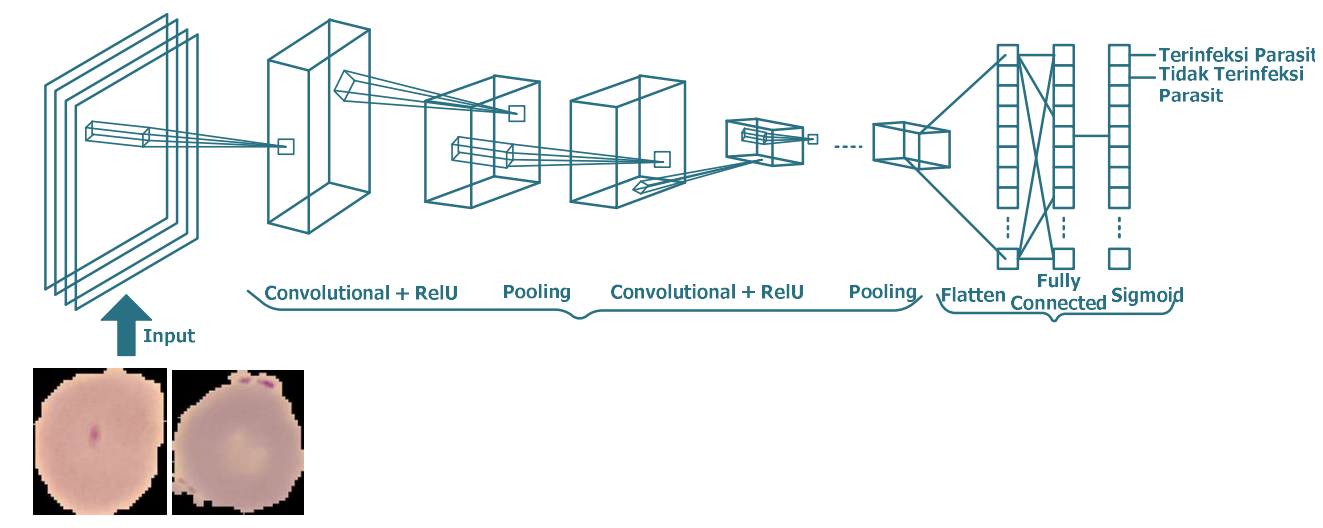

Gambar 1. Tipikal Arsitektur CNN

Keluaran dari convolutional layer disebut dengan feature map, mendiskripsikan ciri-ciri unik dari citra. Convolutional layer teridiri dari filter yang berfungsi untuk melakukan proses konvolusi pada matriks citra masukan. Ide utama dari penggunaan pooling layer adalah untuk mereduksi kompleksitas model yang digunakan dengan cara mengurangi jumlah parameter 
untuk proses komputasi (Albawi, 2017). Kompleksitas model yang tinggi memicu terjadinya kondisi over-fitting. Proses pengurangan parameter dilakukan dengan cara menggabungkan beberapa piksel ketetanggaan dan menjadikanya satu nilai. Proses pooling yang paling umum digunakan adalah max pooling dan average pooling.

\subsection{Dataset}

Dataset yang digunakan dalam penelitian ini diperoleh dari Kaggle Malaria Cell Images Dataset (Medicine, 2017). Total citra yang digunakan adalah 27.560, dibagi menjadi dua kelas yaitu citra terinfeksi parasit malaria (parasitized) dan citra tidak terinfeksi parasit malaria (uninfected). Dari total data, komposisi 75\% (20670 citra) digunakan sebagai data latih dan sisanya sebagai data uji.

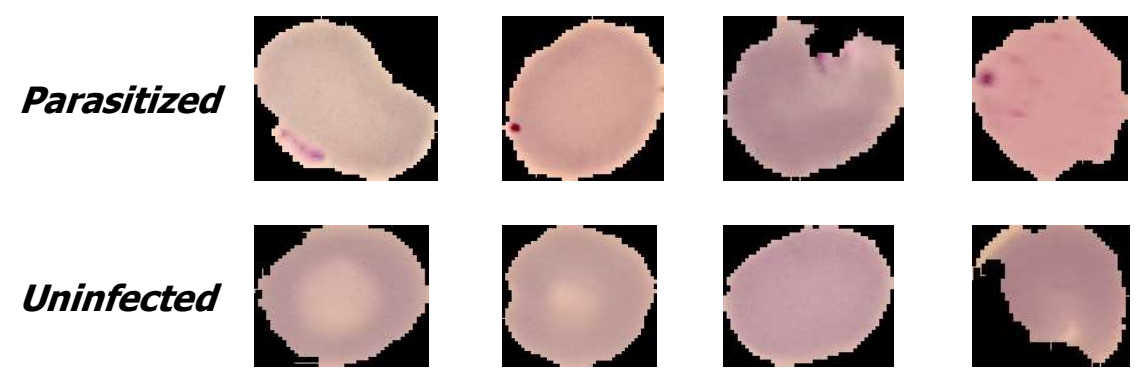

Gambar 3. Sample Dataset yang Digunakan

\subsection{Rancangan Sistem}

Pertama-tama citra akan di-resizing menjadi $64 \times 64$ piksel, citra ini menjadi masukan ke CNN model yang dirancang. Berdasarkan Tabel 1 dan Gambar 4 di bawah, model CNN yang terdiri dari tiga hidden layer. Disetiap hidden layer, citra masukan/feature map akan dikonvolusi dengan filter berukuran $3 \times 3$, menghasilkan kanal keluaran untuk setiap layer masing-masing sebesar 16, 32 dan 64. Setelah melewati proses konvolusi, disetiap layerakan dilakukan proses RelU aktivasi dan max-pooling. Di akhir, terjadi proses flatten, yang berfungsi untuk mengubah fitur citra dari tiga dimensi menjadi satu dimensi agar dapat diklasifikasikan. Pengklasifikasi menggunakan Sigmoid, paling umum untuk binary classification.

Tabel 1. Detail Model CNN yang Diusulkan

\begin{tabular}{|l|c|c|}
\hline \multicolumn{1}{|c|}{ Layer (Type) } & Output Shape & Parameter \\
\hline Input Image & $64,64,3$ & 0 \\
\hline Convolutional\#1 & $64,64,16$ & 448 \\
\hline RelU Activation\#1 & $64,64,16$ & 0 \\
\hline Max-Pooling\#1 & $32,32,16$ & 0 \\
\hline Convolutional\#2 & $32,32,32$ & 4640 \\
\hline RelU Activation\#2 & $32,32,32$ & 0 \\
\hline Max-Pooling\#2 & $16,16,32$ & 0 \\
\hline Convolutional\#3 & $16,16,64$ & 18496 \\
\hline RelU Activation\#3 & $16,16,64$ & 0 \\
\hline Max-Pooling\#3 & $8,8,64$ & 0 \\
\hline Dropout & $8,8,64$ & 0 \\
\hline Flatten & 4096 & 0 \\
\hline Dense & 2 & 8194 \\
\hline
\end{tabular}




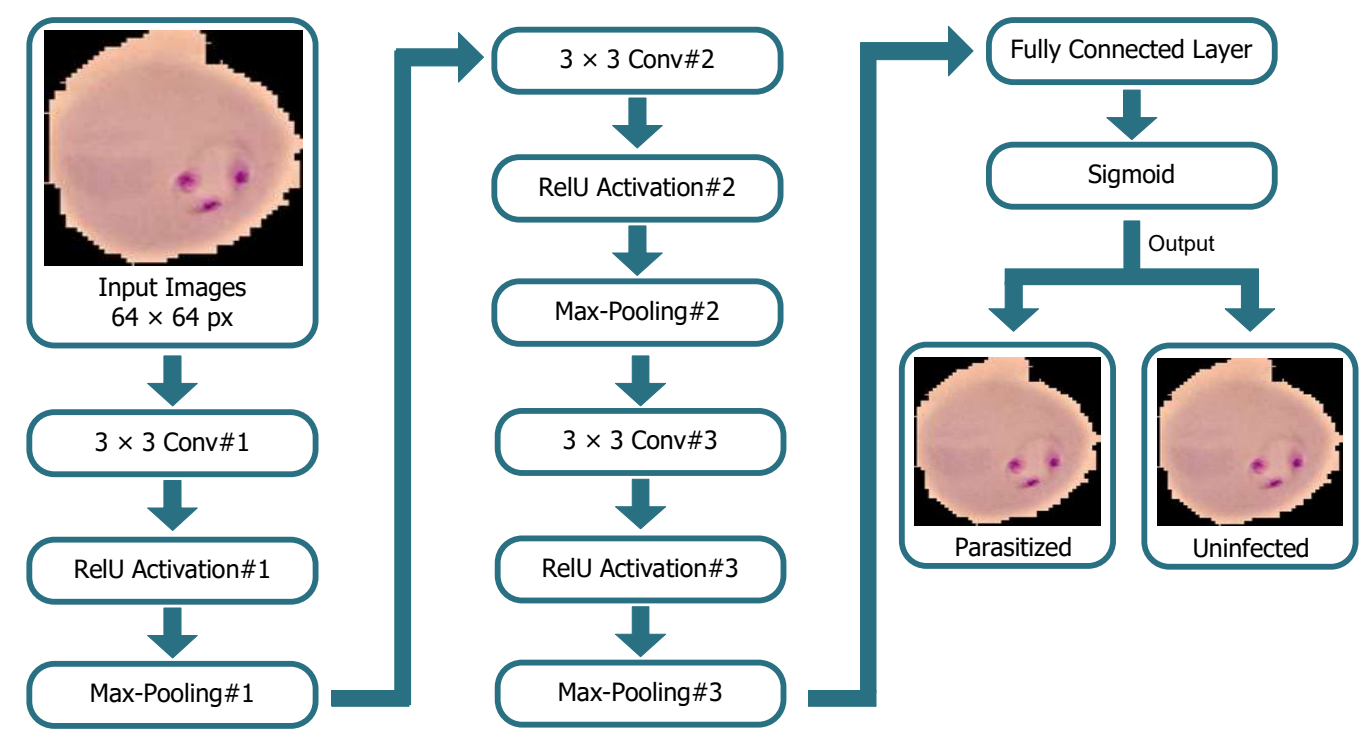

Gambar 4. Model CNN yang Diusulkan

\subsection{Evaluasi}

Confusion matrik berisi informasi terkait klasifikasi data aktual dan prediksi yang telah dilakukan oleh classifier (Santra, 2012). Dalam proses pengumpulan data analisis, data dari confusion matrik bisa digunakan untuk proses evaluasi performansi kinerja sistem. Tabel 2 dibawah menggambarkan Confusion matrik untuk proses klasifikasi dua kelas, yaitu Uninfected dan Parasitized.

Tabel 2. Confusion Matrik untuk Klasifikasi Dua Kelas (Uninfected dan Parasitized)

\begin{tabular}{|l|c|c|}
\cline { 2 - 3 } \multicolumn{1}{c|}{} & Predicted Parasitized & Predicted Uninfected \\
\hline Actual Parasitized & True Positive (TP) & False Negative (FN) \\
\hline
\end{tabular}

Dari confusion matrik bisa dicari besarnya parameter presisi, recall, f1-score dan akurasi. Presisi adalah perbandingan data prediksi positif yang secara aktual benar positif, terhadap keseluruhan data yang terprediksi positif. Recall adalah perbandingan data prediksi positif yang secara aktual benar positif, terhadap keseluruhan data aktual positif. Sangat sulit untuk membandingkan dua model dengan presisi yang tinggi dan recall yang rendah, atau sebaliknya. Untuk melihat bagaimana perbandingannya, digunakan parameter f1-score, yaitu besarnya rata-rata harmonik dari presisi dan recall. Parameter kinerja terakhir adalah akurasi, besarnya perbandingan jumlah data yang diprediksi secara positif terhadap total data.

$$
\begin{gathered}
\text { Presisi }=\frac{T P}{T P+F P} \\
\text { Recall }=\frac{T P}{T P+F N} \\
f 1-\text { Score }=2 \times \frac{\text { Presisi } \times \text { Recall }}{\text { Presisi }+ \text { Recall }} \\
\text { Akurasi }=\frac{T P}{T P+F P+T N+F N}
\end{gathered}
$$




\section{HASIL DAN PEMBAHASAN}

Hasil pengujian beserta dengan pembahasannya secara terperinci akan dituangkan pada bagian ini. Simulasi deteksi parasit malaria dari citra mikroskopis hapusan darah dilakukan menggunakan bahasa pemrograman Python dan library deep learning Keras. Total keseluruhan dataset dibagi menjadi dua, yaitu data latih dan uji, dengan perbandingan sebesar $75 \%$ : 25\%. Proses latih menggunakan learning rate sebesar $10^{-3}$ dengan loss categorical cross-entropy dan dilakukan iterasi sebanyak 100 iterasi. Sedangkan untuk algoritma optimizer, akan dilakukan uji perbandingan terhadap tujuh optimizer yang berbeda; Adam, Nadam, SGD, RMSProp, Adamax, AdaDelta, dan AdaGrad. Hasil pengujian akan dievaluasi dengan menggunakan Persamaan (1), (2), (3) dan (4). Pengaruh algoritma optimizer Adam, Nadam, SGD, RMSProp, Adamax, AdaDelta, dan AdaGrad akan ditunjukkan oleh confusion matrix di bawah ini.
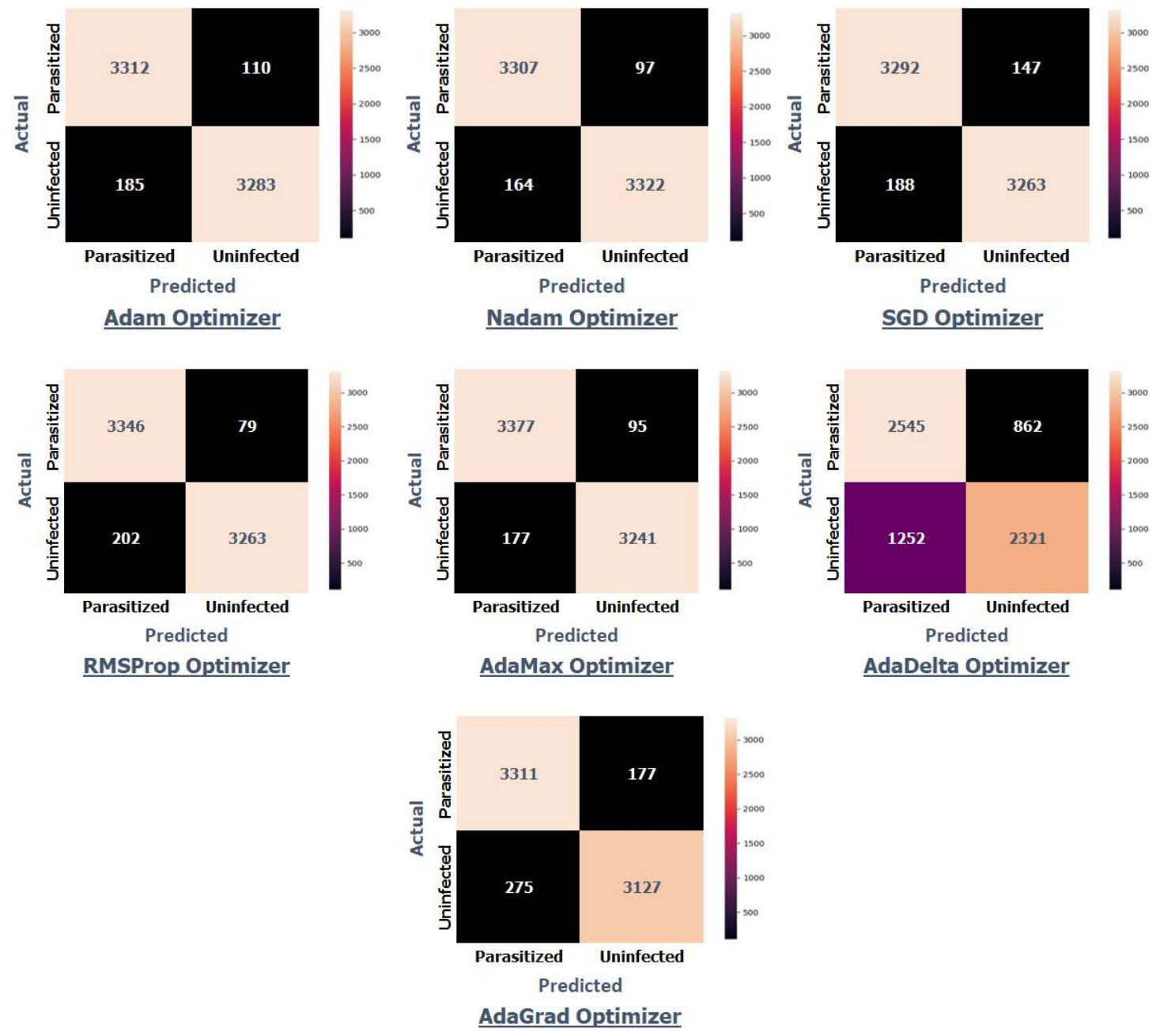

\section{Gambar 5. Confusion Matrix untuk Optimizer yang Berbeda}

Dari confusion matrix di atas, dapat dihitung besarnya presisi, recall dan f1-score untuk setiap optimizer. Dari Gambar 6 di bawah ini terlihat bahwa AdaDelta memberikan nilai presisi yang paling rendah, baik pada saat identifikasi citra terinfeksi parasit malaria (parasitized). Presisi yang rendah pada AdaDelta memberikan arti bahwa optimizer ini memiliki kemampuan yang 
rendah untuk mengenali citra uninfected, setidaknya terdapat 1.253 citra yang secara aktual adalah uninfected, tetapi terprediksi sebagai parasitized. Sebaliknya, nilai recall terendah diberikan oleh AdaDelta untuk citra uninfected, artinya sistem banyak melakukan kesalahan pada citra prediksi parasitized, padahal pada kenyataannya citra tesebut adalah yang tidak terinfeksi (uninfected). Terdapat 862 citra yang terprediksi uninfected padahal kenyataannya citra tersebut adalah citra parasitized.

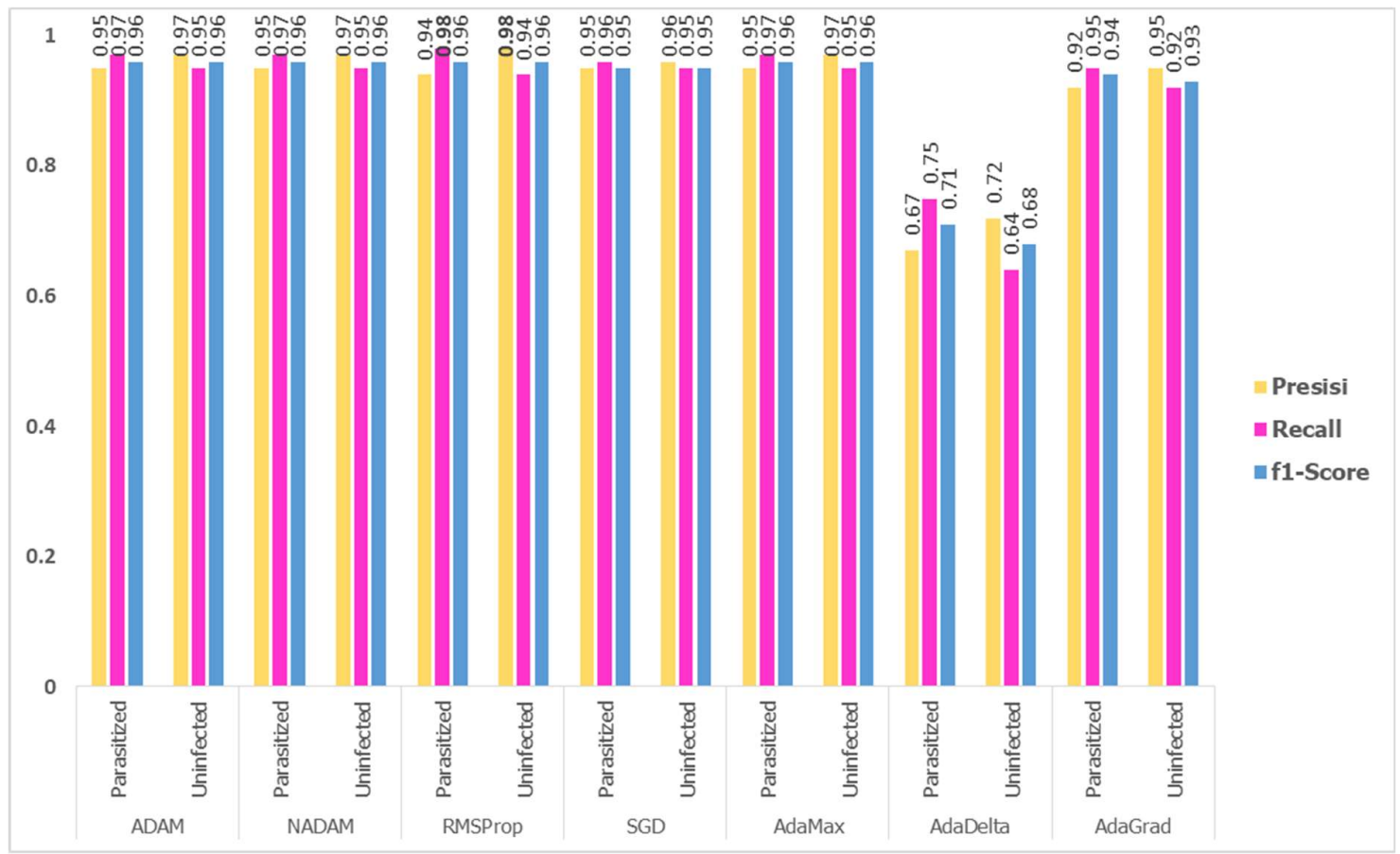

Gambar 6. Presisi, Recall dan f1-Score untuk Optimizeryang Berbeda

Sedangkan presisi dan recal/ terbaik diberikan oleh Optimizer RMSProp, dengan nilai presisi sebesar 0,98 untuk citra uninfected dan recall 0,98 untuk citra parasitized. Nilai presisi menggambarkan tingkat ketepatan antara informasi citra yang sesungguhnya dengan jawaban atau prediksi yang diberikan oleh sistem. Dilihat dari nilai rata-rata presisi, recal/ dan f1-score, optimizer Adam, Nadam, RMSProp, dan AdaMax memiliki kinerja sama terbaik, dengan nilai rata-rata untuk masing-masing sebesar 0,96.

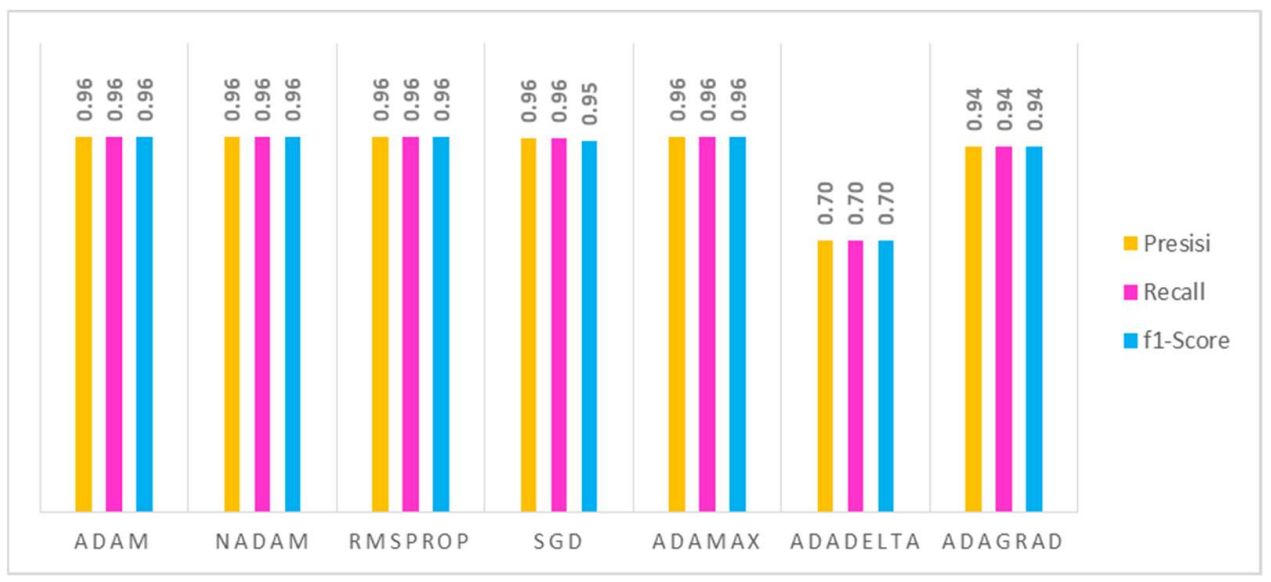

Gambar 7. Rata-Rata Presisi, Recall dan f1-Score untuk Optimizeryang Berbeda 
Selain besarnya presisi, recall dan f1-score, selama proses pelatihan dan validasi juga dievaluasi besarnya akurasi yang diperoleh. Besarnya akurasi latih dan akurasi validasi dapat dilihat dari Gambar 8 dan Gambar 9 di bawah ini. Akurasi latih didapatkan saat model melakukan training terhadap 20670 citra, sedangkan akurasi validasi diperoleh saat model melakukan pengujian terhadap 6890 citra. Dari Gambar 8 terlihat bahwa antara akurasi latih dan akurasi validasi untuk masing-masing optimizer, nilai akurasinya tidak mengalami perbedaan yang jauh, sehingga dapat disimpulkan bahwa model yang diajukan tidak mengalami over-fiiting maupun under-fitting. Kondisi over-fitting biasanya disebabkan oleh kompleksitas model yang tinggi, sehingga model akan terlalu fokus melakukan training terhadap dataset tertentu, akibatnya akan mengurangi kemampuan model dalam melakukan prediksi teradap data yang baru. Sedangkan underfitting terjadi ketika model tidak bisa melakukan prediksi dengan tepat, baik untuk data latih maupun dataset baru yang serupa. Optimizer Nadam merupakan algoritma optimasi yang paling stabil nilai akurasi validasinya, dari awal iterasi sampai dengan akhir, selanjutnya diikuti oleh RMSProp dan Adam.
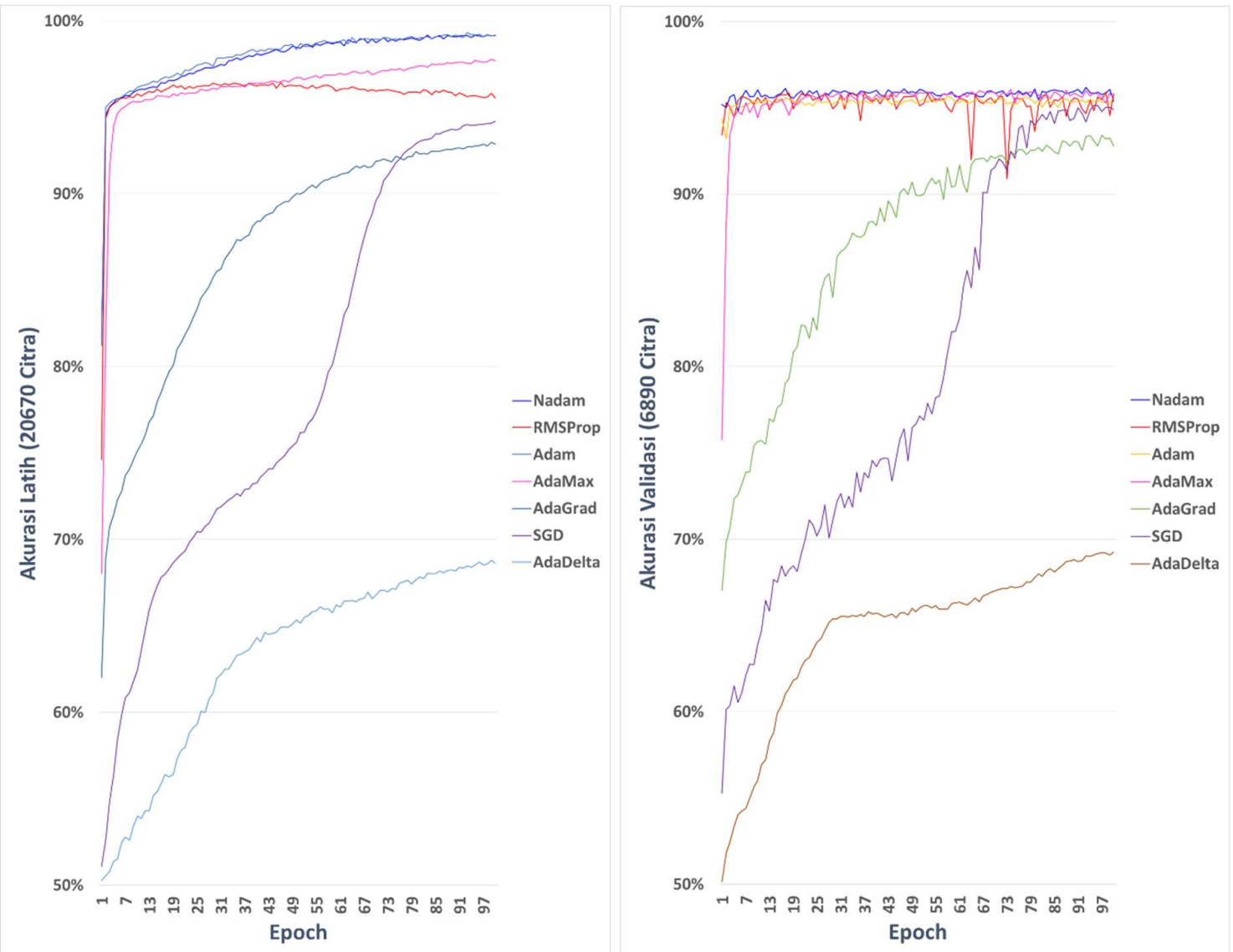

Gambar 8. Akurasi Latih dan Akurasi Validasi untuk Optimizeryang Berbeda

Dari ketujuh algoritma optimizer yang digunakan, diperoleh bahwa akurasi latih rata-rata tertinggi selama 100 epoch diperoleh saat model menggunakan algoritma pengoptimalan Adam, dengan nilai sebesar $99,18 \%$. Sedangkan untuk akurasi validasi rata-rata tertinggi selama 100 epoch diperoleh saat proses updating bobot menggunakan algoritma optimasi RMSProp, dengan nilai sebesar 95,83\%. Sehingga dapat disimpulkan bahwa RMSProp memiliki kemampuan yang tinggi untuk memprediksi data uji dengan benar. Sementara untuk akurasi latih dan validasi terendah dihasilkan oleh AdaDelta optimizer. 


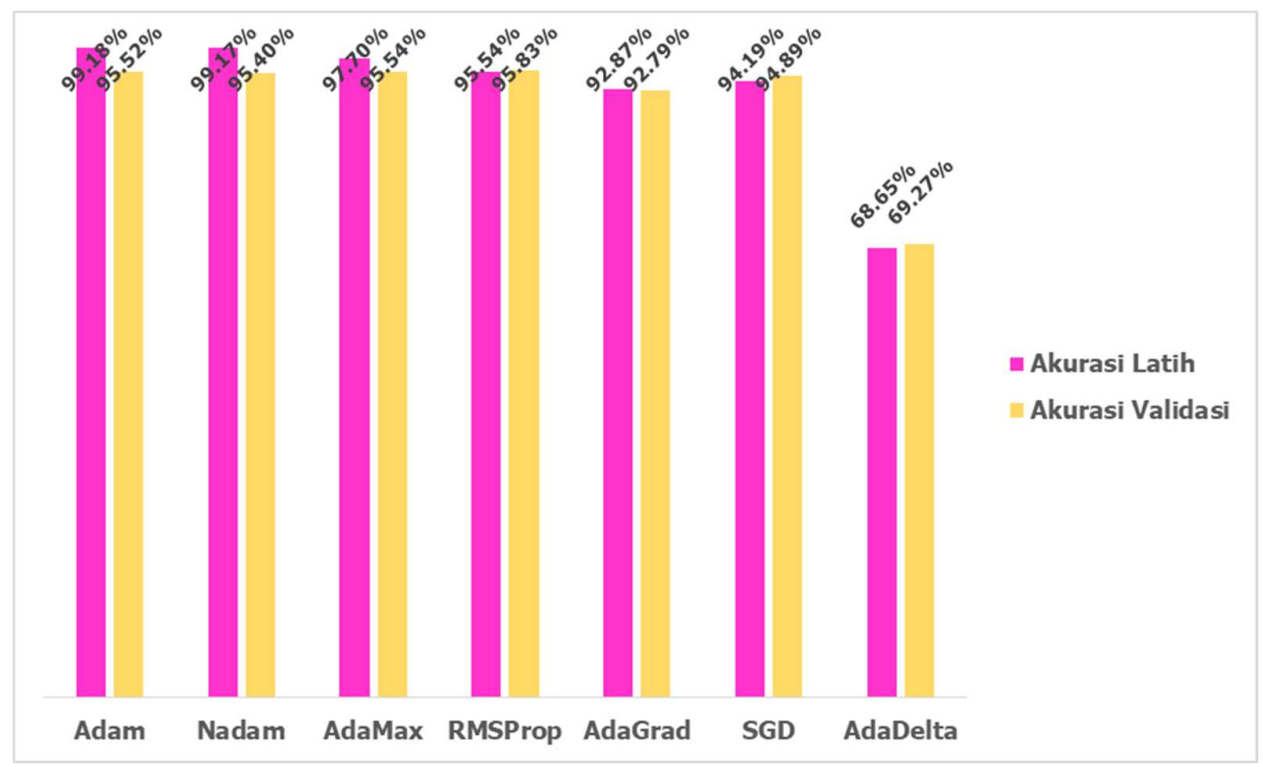

\section{Gambar 9. Akurasi Rata-Rata (100 epoch) untuk Optimizeryang Berbeda}

Selain akurasi, hasil pengujian sistem juga menghasilkan nilai loss. Nilai loss penting untuk dievalusi untuk mengetahui seberapa baik kerja optimizer.
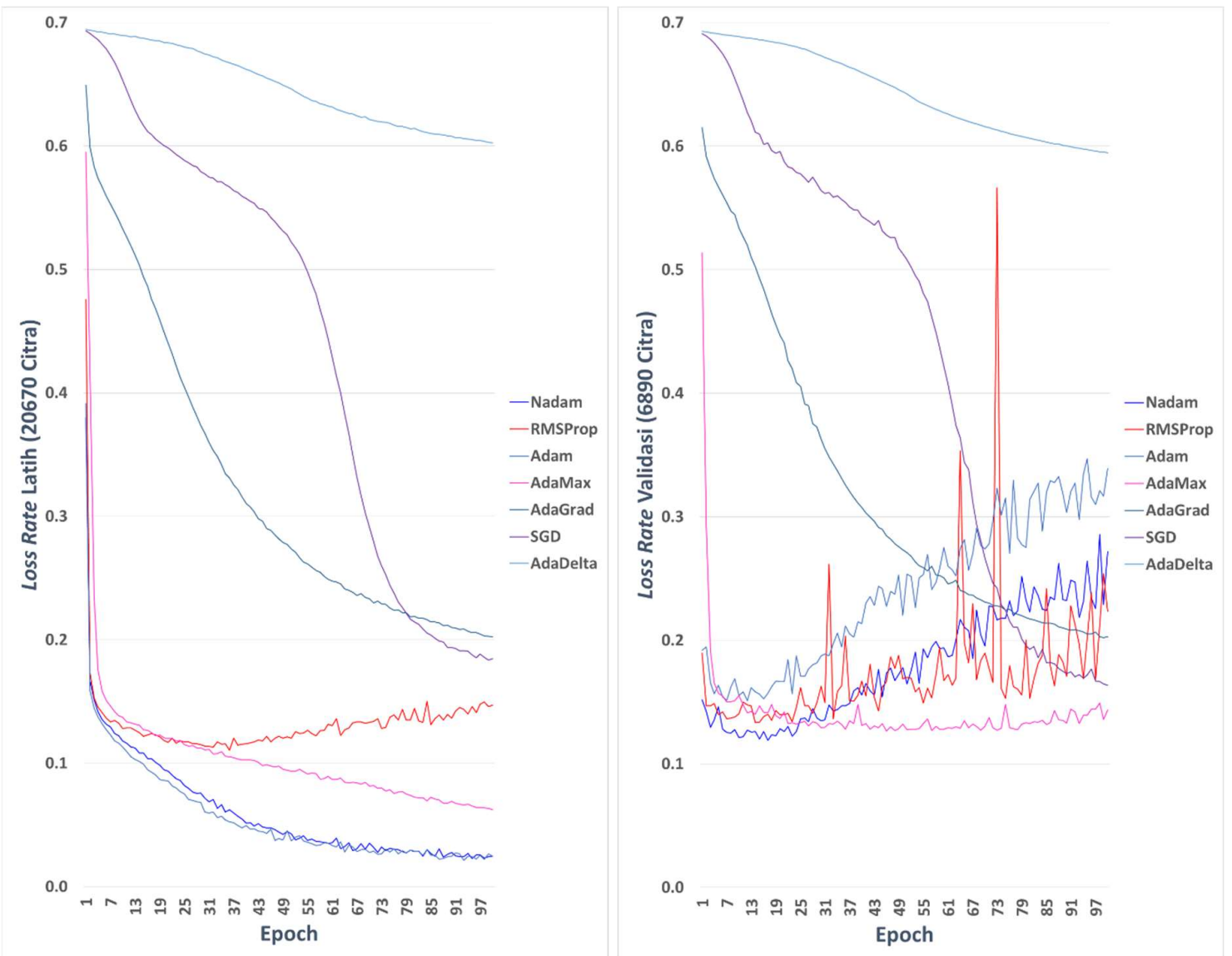

Gambar 10. Loss Rate Latih dan Validasi untuk Optimizer yang Berbeda 
Loss adalah ukuran kuantitatif penyimpangan atau perbedaan antara keluaran yang diprediksi dan keluaran aktual. Sederhananya bisa dikatakan sebagai ukuran kesalahan yang dibuat oleh jaringan dalam memprediksi keluaran. Nilai loss menyiratkan seberapa baik atau buruk performansi model yang dirancang setelah dioptimalkan pada setiap iterasi. Pengoptimalan ini dilakukan dengan cara meng-update nilai vektor bobot dengan harapan akan mengurangi besarnya loss di setiap iterasi. Semakin rendah nilai loss, maka semakin baik modelnya (kecuali jika model tersebut over-fitting). Jika dilihat dari Gambar 10, optimizerAdam memberikan nilai loss minimum saat proses training, sedangkan pada validasi, nilai loss optimizer Adam cenderung meningkat pada setiap iterasi. Pada AdaDelta, SGD dan AdaGrad, walaupun untuk setiap iterasi nilai loss terus turun, tetapi nilai loss masih cukup tinggi. Optimizer yang memberikan nilai akurasi terbaik dan stabil yaitu RMSProp, ternyata memiliki nilai loss yang sedikit berfluktuatif pada iterasi tertentu.

Tabel 3. Perbanding Kinerja Model dengan Penelitian Sebelumnya

\begin{tabular}{|c|c|c|c|c|}
\hline Referensi & Metode & $\begin{array}{l}\text { Jumlah } \\
\text { Kelas }\end{array}$ & $\begin{array}{l}\text { Jumlah } \\
\text { Dataset }\end{array}$ & Akurasi \\
\hline \multirow{5}{*}{ (Qanbar, 2019) } & Alexnet & \multirow{5}{*}{ 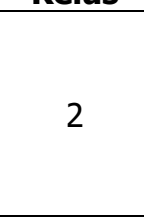 } & \multirow{5}{*}{27558} & $92,64 \%$ \\
\hline & VGG16 & & & $95,04 \%$ \\
\hline & MobileNetV2 & & & $50,00 \%$ \\
\hline & ResNet50 & & & $94,37 \%$ \\
\hline & RAN & & & $95,51 \%$ \\
\hline (Masud, 2020) & $\begin{array}{l}\text { CNN Sederhana (4 } \\
\text { Convolutional Layer \& } 2 \\
\text { Fully Connected Layer) }\end{array}$ & 2 & 27558 & $97,30 \%$ \\
\hline (Shah, 2020) & $\begin{array}{l}\text { CNN Sederhana (3 } \\
\text { Convolutional Layer) }\end{array}$ & 2 & 17460 & $95,26 \%$ \\
\hline (Penas, 2017) & Inceptionv3 CNN & 2 & 363 & $95,20 \%$ \\
\hline (Zein, 2019) & $\begin{array}{l}\text { Resnet (Jumlah Hidden } \\
\text { Layer tidak disebutkan) }\end{array}$ & 2 & $\begin{array}{c}\text { Tidak } \\
\text { disebutkan }\end{array}$ & $97 \%$ \\
\hline \multicolumn{2}{|c|}{$\begin{array}{c}\text { Sistem yang diusulkan (3 Convolutional } \\
\text { Layer \& } 1 \text { Fully Connected Layer) }\end{array}$} & 2 & 27560 & $95,83 \%$ \\
\hline
\end{tabular}

Tabel 3 di atas memberikan informasi perbandingan kinerja model yang diusulkan terhadap kinerja penelitian sejenis sebelumnya. Akurasi yang pada model (Masud, 2020) sebesar $97,30 \%$ diperoleh saat arsitektur menggunakan jumlah layeryang lebih dalam dari model yang diusulkan, sehingga semakin banyak fitur yang dapat diektraksi dan akurasi bisa meningkat. Tetapi jika dibandingkan dengan penelitian lain, model yang penulis usulkan memberikan nilai akurasi yang tinggi yaitu sebesar 95,83\%, dengan kompleksitas komputasi yang cukup sederhana.

\section{KESIMPULAN}

Penelitian memberikan kesimpulan bahwa model CNN sederhana yang terdiri dari tiga hidden layer, dimana setiap hidden layerterdiri dari convolutional layer, RelU aktivasi dan max-pooling dapat melakukan identifikasi adanya parasit malaria pada citra mikroskopis hapusan darah. Model menggunakan learning rate sebesar 0,001 dengan optimizer yang digunakan adalah Adam, Nadam, RMSProp, SGD, AdaMax, AdaDelta, dan AdaGrad. Hasil pengujian dengan menggunakan tujuh optimizer yang berbeda, diperoleh hasil bahwa algoritma optimasi RMSProp memberikan kinerja terbaik dengan nilai presisi dan recal/tertinggi sebesar 0,98, f1score rata-rata sebesar 0,96 dan akurasi validasi sebesar 95,83\%. Sedangkan optimizer 
dengan kinerja terburuk dalam mengidentifikasi citra mikroskopis hapusan darah adalah AdaDelta. Hasil pengujian sistem dengan optimizer AdaDelta diperoleh nilai presisi dan recall sebesar masing 0,67 dan 0,64 dengan f1-score rata-rata sebesar 0,7 dan akurasi validasi sebesar $69,27 \%$. Hasil penelitian secara keseluruhan memiliki tingkat akurasi yang cukup baik, mencapai $95,83 \%$ sehingga dapat dipertimbangkan untuk bisa dilakukan uji klinis lapangan. Setelah proses verifikasi, sistem diharapkan mampu membantu pihak medis dalam mempersingkat waktu diagnosa klinis terhadap penyakit malaria.

\section{DAFTAR RUJUKAN}

Albawi, S., \& Mohammed, T. A. (2017). Understanding of a Convolutional Neural Network. International Conference on Engineering and Technology (ICET), (April 2018), (pp. 16). https://doi.org/10.1109/ICEngTechnol.2017.8308186

Chanda, P., Kapata, N., \& Zumla, A. (2020). International Journal of Infectious Diseases COVID-19 and malaria: A symptom screening challenge for malaria endemic countries. International Journal of Infectious Diseases, 94, 151-153. https://doi.org/10.1016/j.ijid.2020.04.007

Hariyani, Y. S., Hadiyoso, S., \& Siadari, T. S. (2020). Deteksi Penyakit Covid-19 Berdasarkan Citra X-Ray Menggunakan Deep Residual Network. ELKOMIKA: Jurnal Teknik Energi Elektrik, Teknik Telekomunikasi, \& Teknik Elektronika, 8(2), 443-453.

Indolia, S., Kumar, A., Mishra, S. P., \& Asopa, P. (2018). ScienceDirect Conceptual Understanding of Convolutional Neural Network- A Deep Learning Approach. Procedia Computer Science, 132, 679-688. https://doi.org/10.1016/j.procs.2018.05.069

Kemenkes, P. D. D. I. K. K. R. (2016). InfoDatin Malaria2016.

Kim, P. (2017). MATLAB Deep Learning: With Machine Learning, Neural Networks and Artificial Intelligence 1st ed (1 ed.; S. Anglin, M. Moodie, M. Powers, \& K. Endsley, ed.). https://doi.org/10.1007/978-1-4842-2845-6

Masud, M., Alhumyani, H., Alshamrani, S. S., Cheikhrouhou, O., Ibrahim, S., Muhammad, G., \& Hossain, M. S. (2020). Leveraging Deep Learning Techniques for Malaria Parasite Detection Using Mobile Application. Wireless Communications and Mobile Computing, 2020, 1-15.

Mbanefo, A., \& Kumar, N. (2020). Evaluation of Malaria Diagnostic Methods as a Key for Successful Control and Elimination Programs. Journal of Tropical Medicine and Infectious Disease, 5, 1-15.

Medicine, U. S. N. L. of. (2017). Malaria Cell Images Dataset. Diambil 2 September 2020, dari https://www.kaggle.com/iarunava/cell-images-for-detecting-malaria

Ouedraogo, M., Kangoye, D. T., Samadoulougou, S., Rouamba, T., Donne, P., \& 
Deteksi Parasit Plasmodium pada Citra Mikroskopis Hapusan Darah dengan Metode Deep Learning

Samadoulougou, F. K. (2020). Malaria Case Fatality Rate among Children under Five in Burkina Faso: An Assessment of the Spatiotemporal Trends Following the Implementation of Control Programs. International Journal of Environment Research and Public Health, 176), 1-22.

Penas, K. E. delas, Rivera, P. T., \& Naval, P. C. (2017). Malaria Parasite Detection and Species Identification on Thin Blood Smears using a Convolutional Neural Network. ACM International Conference on Connected Health: Applications, Systems and Engineering Technologies (CHASE), (pp. 1-6). https://doi.org/10.1109/CHASE.2017.51

Qanbar, M. M., \& Tasdemir, S. (2019). Detection of Malaria Diseases with Residual Attention Network. International Journal of Intelligent Systems and Applications in Engineering, ス4), 238-244. https://doi.org/10.1039/b000000x

Santra, A. K., \& Christy, C. J. (2012). Genetic Algorithm and Confusion Matrix for Document Clustering. International Journal of Computer Science Issues, 9(1), 322-328.

Shah, D., Kawale, K., Shah, M., Randive, S., \& Mapari, R. (2020). Malaria Parasite Detection Using Deep Learning. International Conference on Intelligent Computing and Control Systems (ICICCS 2020), (pp. 984-988).

Talapko, J., Škrlec, I., Alebic, T., Jukic, M., \& Vcev, A. (2019). Malaria: The Past and the Present. Journal Microorganisms, 76$), 1-17$.

WHO, W. H. O. (2019). World Malaria Report 2019. Diambil 8 September 2020, dari https://www.who.int/publications/i/item/world-malaria-report-2019

Zein, A. (2019). Pendeteksian Penyakit Malaria Menggunakan Medical Images Analisis Dengan Deep Learning Python. Sainstech, 29(1), 48-53. Diambil dari https://ejournal.istn.ac.id/index.php/sainstech/article/view/319 